\title{
Molecular Characterization of 36 Accessions of Two Genera of Cocoyam (Colocasia [Schott] and Xanthosoma [Schott], Araceae)
}

\author{
Osawaru, M.E and Ogwu, M.C* \\ Department of Plant Biology and Biotechnology, Faculty of Life Sciences, University of Benin, \\ Benin City, Nigeria
}

\begin{abstract}
Most popular edible aroid commonly called cocoyam belong to the genera Colocasia (Schott) and Xanthosoma (Schott); are tuber crops introduced into Africa from Asia and tropical America respectively. These crops are grown in all parts of tropical and sub-tropical regions where they have high adaptability, acceptance and serve as auxillary crop plant for food and income security. The present study aims to collect cocoyam germplasm from local agriculture systems in Edo state, Nigeria and characterize them using molecular marker techniques. Random stratified sampling method was used to collect the plant genetic resources based on IBPGR and IPGRI descriptors. Collecting cocoyam germplasm is first reported in Nigeria in this study. Collected germplasm were planted out for trial in a home garden plot situated in the University of Benin, Nigeria. After 6 months, leaves were harvested for Random Amplified Polymorphic DNA (RAPD) analysis to characterize the accessions. RAPD-PCR was conducted at Biochemistry Division, Nigerian Institute of Medical Research (NIMR), Yaba-Lagos state. Differences in the pattern of bands produced after gel electrophoresis reveal the crops are diverse within the state. Dendrogram constructed from the data matrix suggests two trees with varied number of lines. These lines were inferred as different varieties of the species of the two genera. Some of the accessions precisely IA, HD, BB and JC were not clustered into any group. This suggests that these accessions are unique and distinct within and between the two genera of cocoyam. The banding pattern were similar within species and different between species, but was not able to distinguish all the varieties from one another. Cluster analysis gave 8-10 groups in two branches corresponding to specific associations with little filtration observed among these groups. The dendrogram implicates accession BB as been unique among all the thirty six accessions studied. Its intermediate response suggests either a branch off point or pure line. Jaccard's similarity clustered the accessions into six groups. The RAPD-PCR could serve as a basis for other characterization works on the 36 accessions of cocoyam for the basis of conservation and sustainable utilization
\end{abstract}

Article Information

Copyright@2015 STAR Journal, Wollega University. All Rights Reserved.

Article History:

Received : 02-01-2015

Revised : 13-03-2015

Accepted : 18-03-2015

Keywords:

Cocoyam

Colocasia and Xanthosoma

RAPD-PCR Characterization

Molecular technique

Arable crops

Plant Conservation

${ }^{*}$ Corresponding Author:

Ogwu, M.C

E-mail:

matthew.ogwu@uniben.edu

\section{INTRODUCTION}

Cocoyam is a non-specific terms, applied to various edible aroids mostly members of the monocotyledonous family Araceae and order Alismatales (Onwueme, 1978; Singh, 2004; APG, 2009; Mwenye, 2009). According to economic classification Cocoyams are root and tuber crops. Roots and tuber crops are among the oldest, most domesticated and important crops worldwide (PerezPonce, 2007; Lebot, 2009; Owusu-Darko et al., 2014). Colocasia [Schott] and Xanthosoma [Schott] species (Cocoyam) are tuber crops consumed all over the tropics almost all year round. They are important tuberous vegetables cultivated for their edible tubers and tender leaves (Morton, 1972; Suja et al., 2009). However, little is known about their extent of production, cultivation, types as well as the taxonomy of the plant (Talwana et al., 2009, Baruwa and Oke, 2012).
There are two major varieties of Colocasia, namely $C$. esculenta var esculenta, with a large central corm, with suckers and stolons and C. esculenta var antiquorum, characterized with a small central corm and a large number of smaller cormels (Gomez-Beloz and Rivero, 2006; Seetohul et al., 2008). Most edible species of Xanthosoma are either $X$. sagittifolium or X. maffafa (Okoye et al., 2006). Their corms are often difficult to distinguish from those of $\mathrm{C}$. esculentus after their leaves have been removed (Matthews, 2010). Many species and varieties exist in the genus Xanthosoma.

Colocasia is a major plant in South Eastern Nigeria (Opara et al., 2013) whereas Xanthosoma is popular in South Southern and South Western regions of Nigeria. However, both genera are characteristically distinct and localized to different ecozones in Nigeria. Both genera are exotic to Africa. Introduction and spread occurred through 


\section{Ogwu and Osawaru}

different routes. Colocasia has been cultivated in suitable parts of southern Africa for centuries and was probably introduced by the Portuguese traders. Its center of origin of Colocasia is thought to be South East Asia most probably in Eastern India and Bangladesh. Xanthosoma is thought to be from the new world most probably Bolivia and Nicaragua. Xanthosoma species are reported to have originated and first domesticated in tropical America, especially Central America and the Caribbean. It has since spread to South East Asia, the Pacific Islands and Africa. The spread of the crop to the South Pacific and Africa occurred in recent times (Onwueme, 1978; Janseens, 2001). It was spread by the Spanish and Portuguese, who also introduced it to Europe and Asia. It moved from the Caribbean, in the late 19th century to Africa, first to Sierra Leone and then to Ghana (FAO, 1990). Colocasia most likely spread through the African Continent, probably from Zanzibar in the east and the Mediterranean in the north (Eland, 2008) or through Egypt, the Nile basin (FAO, 1990; Mwenye, 2009).

In Nigeria especially southern political states, these crops thrive well in difficult terrains as weed as well as in cultivated land with poor record regarding yield and marketing systems. These crops contribute to food and income security in the Southern region of Nigeria. These notwithstanding, species of these genera are vulnerable to many factors. For example, Colocasia esculentus is seriously threatened to extinction in south eastern Nigeria as a result of its high susceptibility to bacterial leaf blight disease (Opara et al., 2013). The focus of the world on a small number of crops for her needs is increasing the number of underutilized or neglected plants (Adelekan, 2012). Thus, there is an immediate need for collection, characterization and documentation in this study.

Beside morphological characterization, the use of biochemical and molecular characterization are becoming increasing important as they suggest more consistent and specific results. In spite of their relevance cocoyam is yet to receive deliberate research and development effort within tropical regions (Talwana et al., 2009). According to Isikawa et al. (1989) they are applied in different systems to characterize plants and can be used as tags since they are located in loci (chromosomes) where they control specific traits within the organism after interaction with the environment. Molecular markers have several advantages over morphological markersfor improving the efficiency of conventional plant breeding by carrying out selection not directly on the trait of interest but on molecular markers linked to that trait (Mwenye, 2009). Restriction fragment length polymorphism (RFLP), random amplified polymorphic DNA (RAPD), amplified fragment length polymorphisms (AFLPs) and Microsatellites or simple sequence repeats (SSRs) are some of the marker techniques that have been developed and used for plants. The development of Polymerase Chain Reaction (PCR) led to the introduction of RAPD. DNA markers reveal polymorphism in a DNA sequence, or the presence or absence of a particular DNA sequence at a particular site in the genome (normally a restriction site or polymerase chain reaction (PCR) primer binding site). Plant genetic resources are an invaluable resource. The ability to identify genetic variation is indispensable to effective management and use of genetic resources (Rao, 2004). Beeching et al. (1993) stated that a prerequisite for any genetic improvement programme is knowledge of the extent of genetic variation present between genotypes
Sci. Technol. Arts Res. J., Jan-March 2015, 4(1): 27-33

and the genetic distance between all closely related species with which hybrids could be produced. This can be achieved through the characterisation of the germplasm using either morphological, biochemical or genetic markers (Mwenye, 2009). The knowledge of genetic diversity result from analysis and characterization allows evaluation of genetic variability, which is a fundamental element in determining breeding strategies and genetic conservation plans (Gholiazadeh et al., 2008, Mwenye, 2009).

This study is aimed at collecting cocoyam germplasm from southern parts of Nigerria (Edo state); to characterize using Random Amplified Polymorphic DNA analysis (RAPD); generate data that will be beneficial in breeding experiments and genetic conservation of the crop while contributing to knowledge on the taxonomy of these genera and understand observed agronomic polymorphism.

\section{MATERIALS AND METHODS}

Study Area: Thislies between Longitude $06^{0} 04^{1}$ E $06^{0}$ $43^{1} \mathrm{E}$ and Latitude $05^{0} 44^{1} \mathrm{~N}$ and $07^{0} 34^{1} \mathrm{~N}$. The climatic conditions are characterized by two distinct conditions of wet and dry seasons. It experiences high rainfall and humidity for most of the year with an annual average rainfall of $500-2,780 \mathrm{~cm}$ (Ikhile and Aifesehi, 2011). The vegetation is typical of tropical rainforest and slightly of a derived savannah (Osawaru and Ogwu, 2014).

Collection of Cocoyam Germplasm: Cocoyam germplasm missions were carried out in the study area in collaboration with the Plant Conservation Unit, Department of Plant Biology and Biotechnology, University of Benin, Benin City and the local indigenes between January and June 2013. Random stratified sampling was use to select farmers, home gardeners, and senior citizens and semi structured questionnaires were administered. Identification was based on IBPGR (1980) and IPGRI (1991) descriptor for Colocasia and Xanthosoma respectively. Fifty-four accessions were collected. For each accession, a detailed passport data was recorded. They were kept in the Department of Plant Biology and Biotechnology, for further evaluation and studies. The corms were put into miniset of about $100 \mathrm{~g}$ each waiting planting. Cut surfaces of the corm were allowed to dry by exposing it to sunlight for 2 days.

Planting Plot and Husbandry: Planting was done in a home garden plot in Benin City situated at Dentistry Quarters, University of Benin Teaching Hospital. Randomize block design (RBD) was used. The most important agronomic practices during cultivation was daily wetting with 1 liter of distilled water per stand as well as weeding, done once every three weeks.

Collection of Leaf Materials for RAPD-PCR Analysis: After 6 months, from each individual 2 - 3 fresh matured leaves were collected from 36 accessions based on the peculiarity attached by the donor and observations during trials, labelled and kept in polythene bags containing silica gel and stored in ambient temperature until DNA extraction. DNA extraction and RAPD-PCR was done at the Laboratory of Biochemistry Division, Nigerian Institute of Medical Research (NIMR), Yaba, Lagos state, Nigeria. DNA extraction was done on all the accession but due to cost implication only thirty six randomly selected accessions were used for RAPD-PCR (Table 1). 
Table 1: Passport information of the 36 accessions of cocoyam used for RAPD analysis

\begin{tabular}{|c|c|c|c|c|}
\hline No & Accession No. & LGA & Exact Collection Point & Genus \\
\hline 1 & ED/AC/AKD005 & Akoko Edo & Igarra-Bokessimi & Colocasia \\
\hline 2 & ED/AB/AKD003 & Akoko Edo & Igarra-Bokessimi & Colocasia \\
\hline 3 & ED/BA/EGR001 & Egor & Ǔpper Siluko & Xanthosoma \\
\hline 4 & ED/BB/EGR003 & Egor & Owode-Siluko & Xanthosoma \\
\hline 5 & ED/CB/ECT003 & Esan Central & Irrua & Xanthosoma \\
\hline 6 & ED/DC/ENE005 & Esan North East & Uromi Ogbidi & Colocasia \\
\hline 7 & ED/DB/ENE003 & Esan North East & Uromi-Agbor rd & Colocasia \\
\hline 8 & ED/EA/ESE001 & Esan South East & Ubiaja-Ariah & Xanthosoma \\
\hline 9 & ED/EC/ESE005 & Esan South East & Ubiaja-Ukhualen & Colocasia \\
\hline 10 & ED/FA/EWE001 & Esan West & Iruekpen & Colocasia \\
\hline 11 & ED/FC/EWE005 & Esan West & Opoji & Colocasia \\
\hline 12 & ED/GA/ETC001 & Etsako Central & Fugar-Ogbona & Xanthosoma \\
\hline 13 & ED/GC/ETC005 & Etsako Central & Avianwu & Xanthosoma \\
\hline 14 & ED/HA/ETE001 & Etsako East & Agenebode & Colocasia \\
\hline 15 & ED/HC/ETE005 & Etsako East & Igiode & Xanthosoma \\
\hline 16 & ED/IA/ETW001 & Etsako West & Avielle Ubiane & Xanthosoma \\
\hline 17 & ED/IC/ETW005 & Etsako West & Aviele Ubiane & Xanthosoma \\
\hline 18 & ED/JC/IGB005 & Igueben & Idumogo & Colocasia \\
\hline 19 & ED/JB/IGB003 & Igueben & Eguare & Colocasia \\
\hline 20 & ED/KA/IKB001 & Ikpoba okha & Ikpoba hill & Colocasia \\
\hline 21 & ED/KB/IKB003 & Ikpoba okha & Idogbo & Colocasia \\
\hline 22 & ED/LB/ORD003 & Oredo & $3^{\text {rd }}$ Ogbewaise & Colocasia \\
\hline 23 & ED/LC/ORD005 & Oredo & Okpenede & Colocasia \\
\hline 24 & ED/MA/ORH001 & Orhionmwon & Abudu & Xanthosoma \\
\hline 25 & ED/MB/ORH003 & Orhionmwon & Uvbe & Xanthosoma \\
\hline 26 & ED/NC/ONE001 & Ovia North East & Ekhiadolor & Xanthosoma \\
\hline 27 & ED/NA/ONE001 & Ovia North East & Ofunwengbe & Xanthosoma \\
\hline 28 & ED/OB/OSW003 & Ovia South West & Ugbogui & Colocasia \\
\hline 29 & ED/OC/OSW005 & Ovia South West & Obaretin & Colocasia \\
\hline 30 & ED/OA/OSW001 & Ovis South West & Ikoha & Xanthosoma \\
\hline 31 & ED/PA/OWE001 & Owan East & Afuze & Xanthosoma \\
\hline 32 & ED/PB/OWE003 & Owan East & Afuze & Xanthosoma \\
\hline 33 & ED/QB/OWW001 & Owan West & Sabongida Ora & Xanthosoma \\
\hline 34 & ED/QC/OWW005 & Owan West & Ovbiokhumrin & Xanthosoma \\
\hline 35 & ED/RA/UHW001 & Uhunmwode & Eyaen village & Xanthosoma \\
\hline 36 & ED/RC/UHW005 & Uhunmwode & Ehor & Xanthosoma \\
\hline
\end{tabular}

DNA Extraction and RAPD-PCR Analysis: DNA was extracted using IDT Protocol adopted from Keb-Llanes et al. (2002). The concentration and purity of DNA was estimated spectrophotometrically at $260 \mathrm{~nm}$, and 260/280 $\mathrm{nm}$ ratio was determined using a DU 530 Beckman spectrophotometer. Purity was also checked on a $0.8 \%$ agarose gel electrophoresis, using 0.5X TBE buffer. All the stock DNA samples were maintained at $-20^{\circ} \mathrm{C}$. DNA samples were diluted to working concentration of $50 \mathrm{ng} / \mu \mathrm{l}$ for use in RAPD analysis. The DNA aliquots were maintained at $4^{\circ} \mathrm{C}$. Agarose gel $\mathrm{QC}$ was carried out to assess the extracted DNA.

RAPD-PCR reactions were carried out using the Ready-To-Go RAPD Analysis beads, which are room temperature-stable were optimized for RAPD reactions. Each bead contains thermo stable polymerases (AmpliTaq $^{\mathrm{TM}}$ DNA polymerase and Stoffel fragment), dNTPs $(0.4 \mathrm{mM}$ each dNTP in a $25 \mu$ reaction volume), BSA $(2.5 \mu \mathrm{g})$ and buffer $(3 \mathrm{mM}$ Magnesium Chloride, $30 \mathrm{mM}$ Potassium Chloride), and $10 \mathrm{mM}$ Tris (pH 8.3) in a $25 \mu \mathrm{l}$ reaction volume. To this $25 \mathrm{pmol}$ of primer and $50 \mathrm{ng}$ of genomic DNA were added.

Amplification was carried out on a Techne Master Thermocycler, Ver B. 1.7 PCR machine. The machine was programmed to 1 cycle of 5 minutes of initial denaturation at $94^{\circ} \mathrm{C}$. This was followed by 40 cycles of 1 minute at $94{ }^{\circ} \mathrm{C}$ for denaturation, 1 minute at $36{ }^{\circ} \mathrm{C}$ for annealing, and 2 minutes at $72{ }^{\circ} \mathrm{C}$ for extension. The final extension was carried out at $72{ }^{\circ} \mathrm{C}$ for 7 minutes. The primer set used for the present analysis is OPA-9 a 10mer RAPD primers. Attempts were made to utlize OPA-2
AND OPA-13 but both produced no electrophoretic bands. OPA-9 was screened and used in RAPD-PCR of extracted DNA from Cocoyam. The sequence of the primer is given thus 5'- GGG TAA CGC C -3'.

After the PCR, $6 \mu$ l of the RAPD products were resolved on a $1.6 \%$ agarose gel using $0.5 \mathrm{X}$ TBE buffer. To carry out the agarose gel electrophoresis, molten agarose was used and Ethidium bromide and mixed well. This was poured into the electrophoresis cast and allowed to solidify at room temperature. When the agarose was solidified, the comb was removed and electrophoresis apparatus was filled with $0.5 \mathrm{X}$ TBE. The samples were mixed with $2 \mu \mathrm{l}$ of the loading buffer and loaded in the wells. A $1000 \mathrm{bp}$ ladder was also loaded in one of the wells. This was then electrophoresed at a constant voltage of $70 \mathrm{~V}$. The gel product was placed on a UV transilluminator and photographed under using a 15 mega pixel Sony digital camera.

Data Analysis: Dominant marker exhibits a present/absent behaviour on the electrophoresis gel. A matrix was generated assuming each RAPD band as a unit character, and presence of a band was represented as 1 and absence as 0 . This matrix was used for generating the Jaccard's similarity coefficient for RAPD bands using Multivariate Analysis System of Multivariate Statistical Package (MSVP). Dendrograms wasalso constructed to depict (1) each marker band represented the phenotype at a single biallelic, distinct locus and, (2) that populations are in Hardy-Weinberg equilibrium. 
Ogwu and Osawaru

\section{RESULTS}

Results are presented in Plate 1 and Figures 1 and 2. The electrophoresis product of RAPD analysis is presented in Plate 1. The electrophoresis product showed the differential response of the different cocoyam accessions. No bands were obtained for some accessions at all the bp while others responded differently at each bp.
Sci. Technol. Arts Res. J., Jan-March 2015, 4(1): 27-33

Clustering of cocoyam accessions based on Jaccard's similarity coefficientby MVSP software is presented in Figure 1. The two branches obtained separated the accessions into Colocasia and Xanthosoma.

Analysis of the binary matrix obtained from scoring electrophoretic product of the RAPD analysis based on their polymorphism is presented in Figure 2.
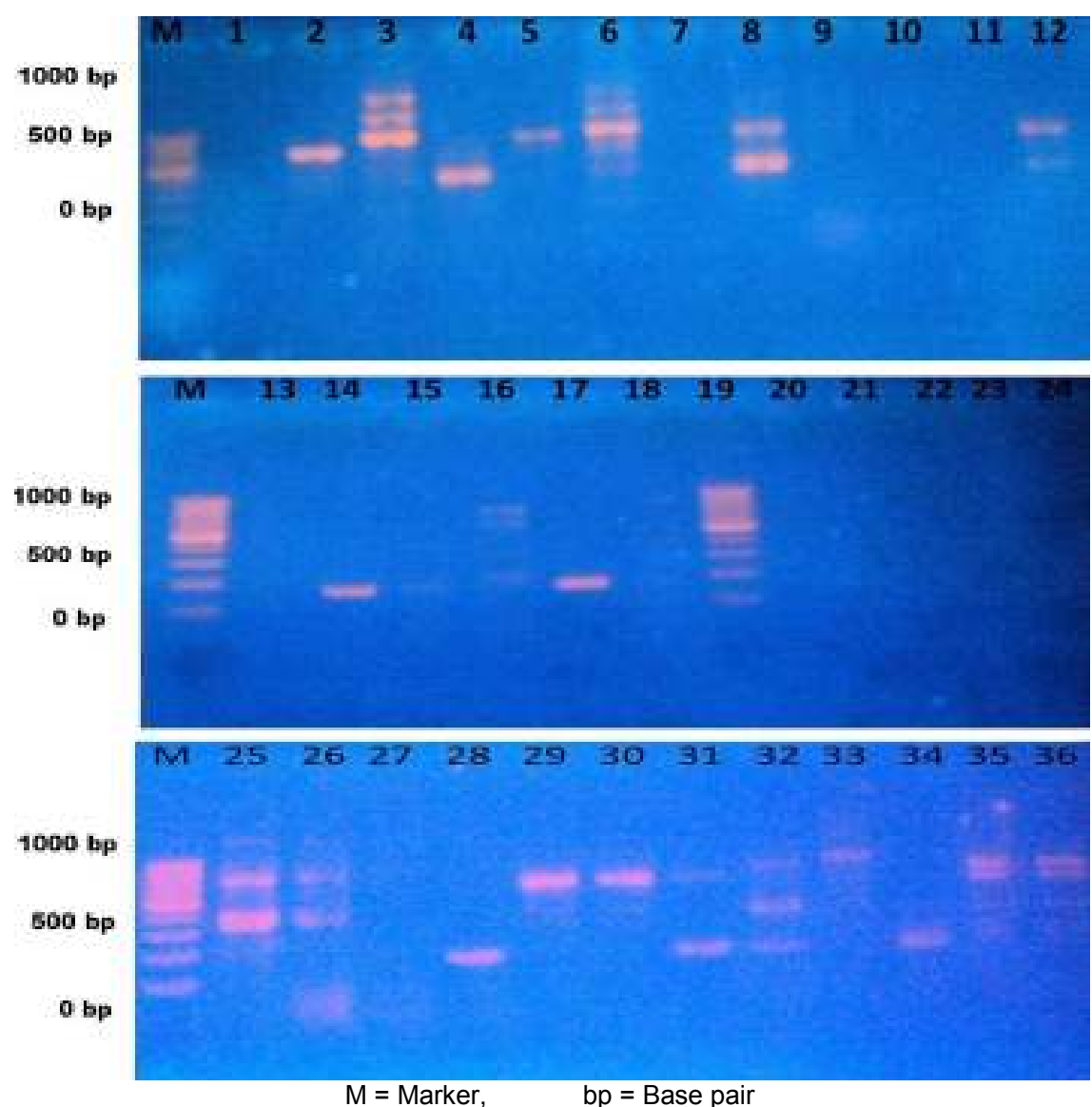

For the purpose of expressing RAPD-PCR result the accession number were used thus: $1=\mathrm{AC}, 2=\mathrm{AB}, 3=\mathrm{BA}, 4=\mathrm{BB}, 5=\mathrm{CB}, 6=\mathrm{DC}, 7=\mathrm{DB}, 8=\mathrm{EA}, 9=$ $\mathrm{EC}, 10=\mathrm{FA}, 11=\mathrm{FC}, 12=\mathrm{GA}, 13=\mathrm{GC}, 14=\mathrm{HA}, 15=\mathrm{HC}, 16=\mathrm{IA}, 17=\mathrm{IC}, 18=\mathrm{JC}, 19=\mathrm{JB}, 20=\mathrm{KA}, 21=\mathrm{KB}, 22=\mathrm{LB}, 23=\mathrm{LC}, 24=\mathrm{MA}, 25=\mathrm{MB}, 26=\mathrm{NC}, 27=$ NA, 28=OB, 29=OC, 30= OA, 31=PA, 32=PB, 33= QB, 34= QC, 35= RA, 36= RC

Plate 1: RAPD-PCR electrophoretic result of 36 accessions of Cocoyam UPGMA

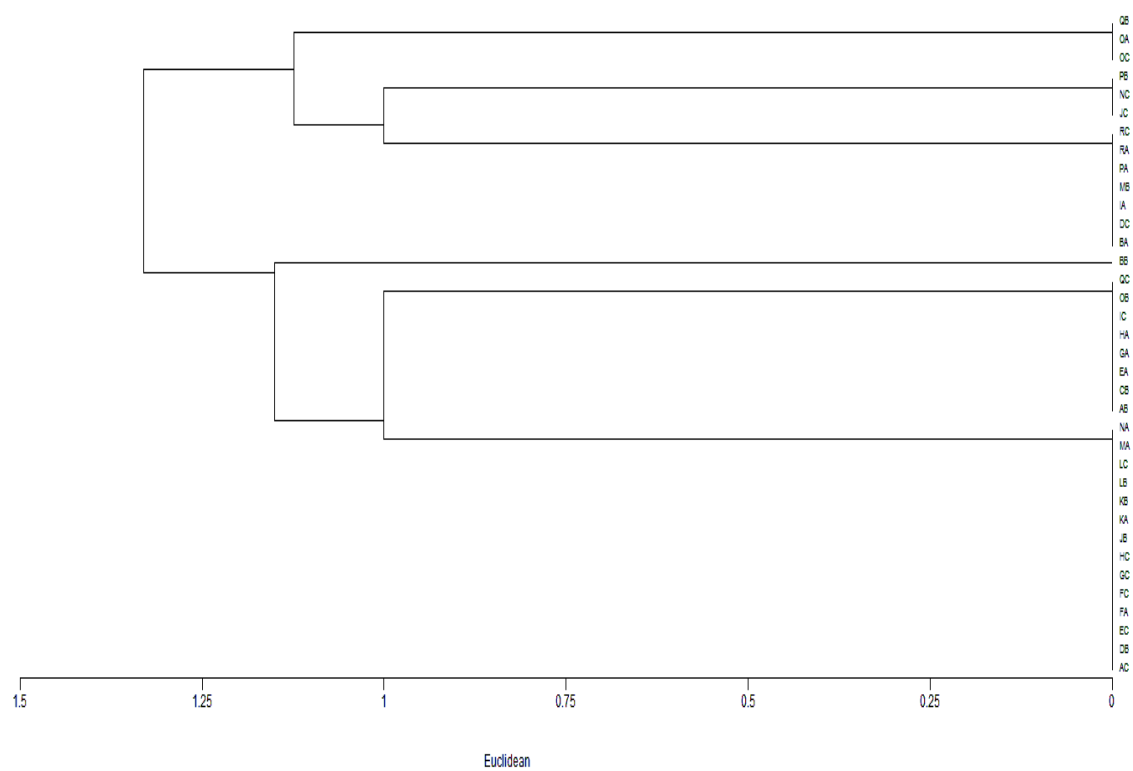

Figure 1: Dendrogram depicting the Jaccard's similarity coefficient of the 36 cocoyam accessions 


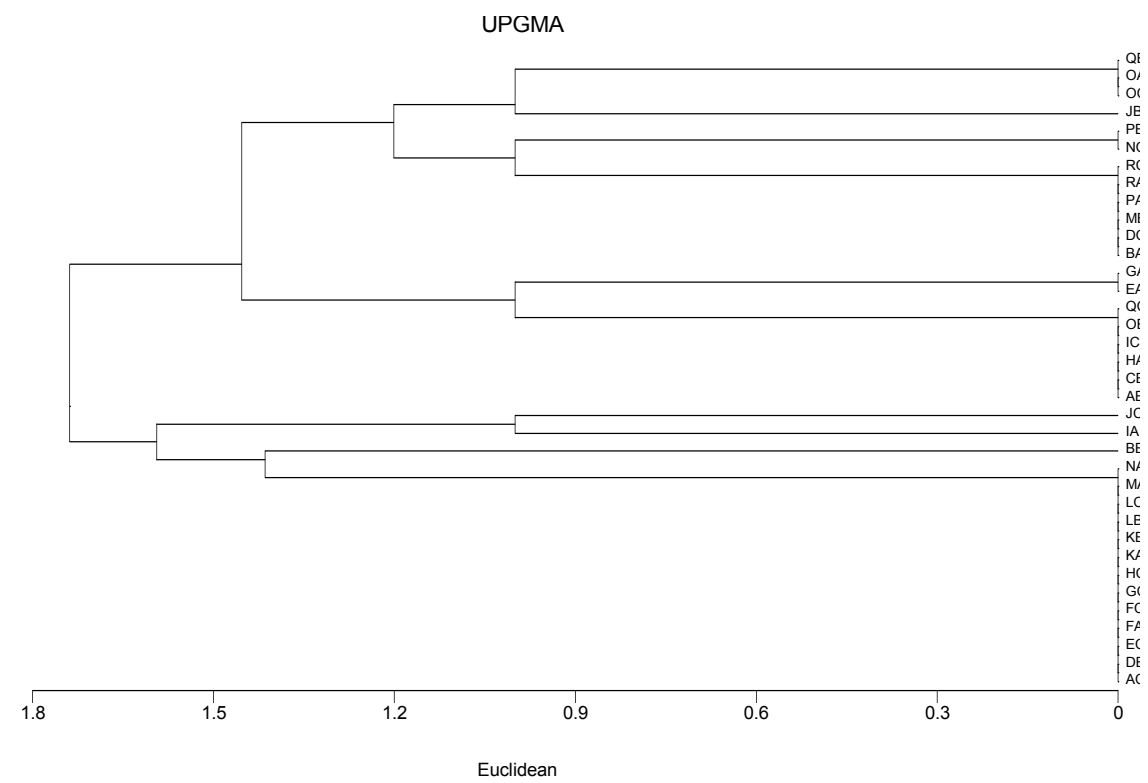

Figure 2: Dendrogram depicting the polymorphic characteristics of the 36 cocoyam accessions

\section{DISCUSSION}

Cocoyam is an important tuber crop in tropical and sub-tropical regions. These crops when properly harnessed can contribute to alleviate the suffering of good number of households (Baruwa and Oke, 2012). They have been ignored in spite of their adaptability, acceptance and commercial food value and have received little attention by researchers (National Academy of Science, 1975; Ekwe et al., 2009, Mwenye, 2009; Global forum for underutilized species, 2009). All these can be implicated for the underutilized status of cocoyam. There is misunderstanding as to the use of vernacular names for this cropswithout distinction among the genera (Janseens, 2001, Mwenye, 2009). Names and naming for these crops need to be standardized to ease identification. The study attempt to provide data that could be used to elucidate key issues and improve knowledge on these crops. Knowledge of genetic diversity and relationships among cocoyam germplasm may play significant role in breeding programmes to biotic and abiotic requirements as well as conservation goals.

Characterization and quantification of genetic diversity has long been a major goal in evolutionary biology as such information is integral for rational use of plant genetic resources (Aladele, 2009). Such information will be relevant in elucidating genetic relationship within and among species (Chakravarthi and Naravaneni, 2006). Markers and marker techniques are now essential to conserve and use plant genetic resources.

Despite these production figures little data is available on these crops. Different national and international organizations, local communities, and even researchers from different disciplines identify and evaluate biodiversity differently (Caillon and Degeorges, 2007). These can include most especially agro morphological, biochemical or anatomical and molecular considerations. In this study, attempts were made to understand the diversity within the cocoyam genera collected from different locations within Edo State, Nigerian. The primer OPA-9 gave 108 scorable bands (Plate 1). The morphological variants were distinguished by the primer used. This is similar to what Perez-Ponce (2007) reported for RAPD analysis of 44 accessions of cocoyam. A total of 44 amplicons were generated in the study. These amplicons ranged between $0 \mathrm{bp}$ and $1000 \mathrm{Bb}$. The amplification obtained showed that the 36 cocoyam accessions responded to the primer different. This was not in total agreement with the observations of Thaker et al. (2011), that one band absent in Colocasia and present in Xanthosoma shows some variants are present which cannot be easily placed in either genera. The presence of one band and/or the absence suggests two significant findings: (i) A distinct variation in DNA pattern was observed between two morphological variants of two cocoyam genera and (ii) Furthermore, DNA amplification patterns using RAPD primers showed polymorphism within DNA from morphological variants (Thaker et al., 2011). DNA polymorphisms are indeed very useful for genetic mapping and can be defined as any difference in the nucleotide sequence between individuals including can be single base pair changes, deletions, insertions, or even changes in the number of copies of a given DNA sequence. SNPs (single nucleotide polymorphisms) (Nature Education, 2013).

RAPD analysis is generally considered a very good starting point for characterization studies of species (Williams et al., 1990). This has also been proven true by the present investigation. This distinctions observed by their molecular characterization will be handy during morphological and biochemical characterization. More so, the results show that modified method is optimal for DNA isolation from morphological variants of taxa as in Cocoyam. Method of extracting pure DNA is important and is not the same for all plant species. The DNA extracted method adopted in this study can also be suggested as suitable for molecular analysis of the two genera.

The quality of extracted DNA was analyzed by means of agarose gel electrophoresis $(0.8 \%)$, followed by ethidium bromide staining $(0.5 \mathrm{mg} / \mathrm{ml})$. The purity of the DNA was estimated by spectrophotometry by calculating the $A 260 / 280$ and $A 260 / 230$ ratios, and the yield was estimated by measuring absorbance at $260 \mathrm{~nm}$. RAPD profile suggests DNA polymorphism among both variants, which proves that there was either environmental/ chemical influence or certain variation that lead to 


\section{Ogwu and Osawaru}

mutation in plant genome. For future studies, the primers selection can be extended in order to effectively compare their effects. Production of cocoyam in many tropical and subtropical countries is mainly for family subsistence through income and food security. In the study by Okoye et al. (2006) to determine allocative effieciency of cocoyam in part of Nigeria there result suggest that age, education, farm size, farm experience, fertilizer use and credit access have direct contribution less so for extension visit, family size and membership of cooperative societies.

RAPD results suggest two distinct genepools as revealed from gel electrophoresis. This was also observed and exploited during the selected process for the markers and primers to be used. As markers and primers pooled for used were first tested to determine their efficiency in distinguishing them. Genetic mapping involves measuring the amount of recombination that occurs between two markers during meiosis. If there is a low amount of recombination between markers, then they are linked (i.e., located very close to each other on the same chromosome). Originally, the markers used by geneticists for genetic mapping experiments included alleles of genes that produced different physical phenotypes (traits) (Nature Education, 2013). DNA polymorphisms can be used in much the same way as these physical phenotypes. Different forms of DNA polymorphisms can be tracked using a variety of techniques. Some of these techniques include Southern blots, PCR (polymerase chain reaction), and hybridization techniques using DNA microarray chips. These techniques allow us to determine if a specific DNA polymorphism is linked to a specific phenotype. We can then conclude that the gene responsible for a given phenotype maps to a chromosomal location very close to the DNA polymorphism (Nature Education, 2013).

DNA polymorphisms are such a powerful tool for mapping human diseases that several projects are underway to identify DNA polymorphisms in humans and to make this data publicly available to scientists worldwide. Two groups that are involved in these massive efforts include the SNP consortium (TSC) and the DNA Polymorphism Discovery Resource. These genetic variations between individuals (particularly in non-coding parts of the genome) are exploited in DNA fingerprinting, which is used in forensic science. Also, these genetic variations underlie differences in our susceptibility to disease. Respond to pathogens, chemicals, drugs, vaccines, and other agents. The principle will be applicable in breeding programs.

The banding patterns were similar within species and different between species, but not able to distinguish all the varieties from one another. Cluster analysis on pooled data from the primers gave 8-10 groups corresponding to morphological species. In the dendrogram of Jaccard's similarity coefficients, six groups were identified and two trees formed individual branches of the dendrogram (Figure 4). The first cluster included four genotypes from region with 3 branches. The first and second clusters were made up of 3 accessions each; including $P B, R A$ and $Q C$ (in the first cluster) and RC, NC and IA (in the second cluster). The third cluster in the first tree contains seven accessions including MB, NC, QB, MA, HC, EA and $B A$. The second tree with also three branches/clusters, the first cluster is the smallest with only accession BB
Sci. Technol. Arts Res. J., Jan-March 2015, 4(1): 27-33

while the second cluster has eight accessions (OC, PA, IC, CC, GC, FA, DC and AC). The last cluster is the largest with fourteen accessions including $O C, L B, L C$, $\mathrm{KB}, \mathrm{KA}, \mathrm{JC}, \mathrm{JC}, \mathrm{HA}, \mathrm{CC}, \mathrm{DC}, \mathrm{GA}, \mathrm{FC}, \mathrm{EC}$ and $\mathrm{AC}$. The dendrogram implicates accession $\mathrm{BB}$ as been unic among all the thirty six accessions studied. It may be inferred that it belongs to a separate variety from either of the two genera of cocoyam. All the other accessions studied had similar genotypes as reflected by the dendrogram. More so, this also suggests that the pairs grouped together have the same genotype but collected at different locations and time.

Markers are assumed to amplify only dominant allele per locus hence amplification products as shown in figure 1 is assumed to refer to the allele at that locus. A locus can be considered polymorphic by the presence or absence of bands on particular accession that polymorphic when absence in some and monomorphic if presence in all the accessions (Al Nashash et al., 2007). On this basis the dendrogram on figure 4 was constructed to depict accessions with polymorphic and monomorphic characteristics. A total of 10 groups were formed from the dendrogram. The first branch of the tree has six clusters thus: $\mathrm{PB}, \mathrm{RA}$ and $\mathrm{QC}$ are group together, accession JC was isolated in its own group, $\mathrm{RC}$ and $\mathrm{NC}$ are grouped together, MB, NC, QB, MA, EA and BA; GC and FA while OC, PA, IC, CC, DC and AC were also place together in a group. The second branch of the tree has four groups mostly made up of monomorphic groups with only one accession including $\mathrm{IA}, \mathrm{HC}$ and $\mathrm{BB}$ while the polymorphic group in this branch including 13 accessions (OC, LB, LC, $\mathrm{KB}, \mathrm{KA}, \mathrm{JC}, \mathrm{HA}, \mathrm{OC}, \mathrm{DC}, \mathrm{GA}, \mathrm{FC}, \mathrm{EC}$ and $\mathrm{AC})$. The grouping of cocoyam accessions with similar banding pattern is in accordance with the results of Shnell et al. (1999). These suggest genetic variation exists among and within the accessions used for the study. Some accessions were unic and require further studies using molecular, biochemical and morphological tools. All the accessions were clearly split into two groups which may imply different genera.

\section{CONCLUSION}

This RAPD-PCR study implicates high level of polymorphism in their genetic makeup. There is need for further molecular characterization studies for these genera to assist in more systematic elucidation. More so, there is need to use different markers for RAPD-PCR analysis of the cocoyam accessions. Due to cost and infrastructure challenges could not be applied in the present study. Diversity of the crops in Edo state is enormous. Most of their varieties are represented. Cost was a limiting factor in this aspect of the study. Others include land and research facilities. With the assistance of effective policy and Government Department, these and other limiting factors can be put to check. Mobilization of small scale cocoyam farmers will contribute to ensure proper management and utilization of yields.

\section{Conflict of Interest}

Authors declared no conflict of interest

\section{REFERENCES}

Adelekan, B.A. (2012). An evaluation of the global potential of cocoyam (Colocasia and Xanthosoma) species) as an energy crop.British Journal of Applied Science and Technology 2(1): 1-15. 


\section{Ogwu and Osawaru}

Aladele, S.E., Ariyo, O.J. and de Lapena, R. (2008). Genetic relationships among West African Okra and Asian genotypes (Abelmoschusesculentus) using RAPD. African Journal of Biotechnology 7(10):1426-1431.

Baruwa, O.I. and Oke, J.T. (2013). Analysis of the Technical Efficiency of Small-holder Cocoyam Farms in Ondo State, Nigeria.Tropicultura 30(1): 36-40

Beeching, J., Marmey, P., Garada, M., Nairot, M., Haysom, H., Hughes, M., and Charrier, A. (1993). An assessment of genetic diversity within collections of cassava (Manihot esculenta Crantz) germplasm using molecular markers. Annals of Botany 72: 515-520.

Caillon, S. and Degeorges, P. (2007). Biodiversity: negotiating the border between nature and culture. Biodivers Conservation 16:2919-2931.

Ekwe, K., Nwosu, K., Ekwe, C. and Nwachukwu, I. (2009). Examining the underexploited values of Cocoyams (Colocasia and Xanthosoma species) for enhanced household food security, nutrition \& economy in Nigeria. In: Jaenicke, H., Ganry, J., Zeledon-Hoeschle, I., Kahane, R. (Eds.). Proceedings of the international symposium on underutilized plants for food security, income and sustainable development. Acta Horticulturae 806: 71-78.

Eland, S. (2008). Plant Biograhies: Colocasiaesculentus. [Available at www.plantlives.com/bibliography.htm accessed 17 may, 2013 at 1451 GMT].

Food and Agriculture Organisation of the United Nations. FAO (1990). Roots, tubers, plantain and bananas in human nutrition, Food and Nutrition series, No. 24: FAO code: 86, AGRIS: SO1 ISBN 92-5-102862-1. Rome.

Gholiazadeh, M., Mianji, G.R. and Zadeh, H.S. (2008). Potential use of molecular markers in genetic improvement of livestock.Asian Journal of Animal and Veterinary Advances 3: 120-128.

Global forum for underutilised species. (2009). http://www.underutilisedspecies.org/about GFU.asp

Gomez-Beloz, A. and Tirzo Rivero, T. (2006). Ure (Colocasia esculenta - Araceae): An Edible Aroid of the Warao. Ethnobotany Research and Applications 4:103-111.

IBPGR (1980). Descriptors for Colocasia.IBPGR Executive Secretariate Rome, Italy. 16p.

Ikhile, C.I. and Aifesehi, P.E. (2011). Geographical Distribution of Average Monthly Rainfall in the Western Section of Benin- Owena River Basin, Nigeria. African Research Review Journal Ethiopia 5(4): 493-50.

IPGRI (1991). Descriptors for Xanthosoma.IBPGR Executive Secretariate Rome, Italy. 34p

Ishikawa, R., Morishima, H., Mori, K., Kinoshita, T. (1989). Chromosomal analysis of isozyme loci and the allelic expression at cellular level in genetical studies on rice plants. Journal of the Faculty of Agriculture 64(1): 85-98.

Janseens, M. (2001). Crop production in tropical Africa Bonn, Germany: Institut fur obstund germusebau, abt. Tropicscher pflanzenbau, rheinische friedrich-wilhelmsUniversitat Bonn, auf dem hugel 6, D-53121 Bonn, Germany. Directorate general for international cooperation, karmelietenstraat 15, B-1000 Brussels, Belgium, pp. 221- 228.

Keb-Llanes, M., González, G., Chi-Manzanero, B. and Infante, D. (2002). A rapid and simple method for smallscale DNA extraction in Agavaceae and Other tropical plants. Plant Molecular Biology Reporter 20: 299a-299e.

Lebot, V. (2009). Tropical Root and Tuber Crops: Cassava, Sweet Potato, Yams and Aroids. Centre de Coopération Internationale en Recherche Agronomique pour le Dévelopement (CIRAD), France. MPG Biddles Ltd, UK.
Sci. Technol. Arts Res. J., Jan-March 2015, 4(1): 27-33

Matthews, P.J. (2010). Earliest uses and cultivation of taro. In: The Global Diversity of Taro Ethnobotany and Conservation. Rao, R.V, Matthews, J.P., Eyzaguirre, P. B. \& Hunter, $D$ (eds). Bioversity International, Rome, Italy 6-8

Morton, J.F. (1972). Cocoyams (Xanthosomacaracu, X. atrovirens and $X$. nigrum), ancient root and leaf vegetables, gaining in economic importance. Vegetable Section. Florida State Horticultural Society 89-94.

Mwenye, O.J. (2009). Genetic diversity analysis and nutritional assessment of Cocoyam genotypes in Malawi. MSc ThesisUniversity of the Free State, Bloemfontein, South Africa. 147p.

National Academy of Science.(1975). Underxploited tropical plants with promising economic.Report of ad hoc panel of the advisory committee on technology inovations, national academy of sciences, USA. Washington D.C.

Nature Education (2013). What is DNA polymorphism and how it helps in genetic mapping? Available online at http://www.nature.com/scitable/popular-discussion/ 680 Accessed on $5^{\text {th }}$ December, 2013 at 1207 Hours GMT.

Okoye, B.C, Onyenweaku, C.E. and Asumugha, G.N. (2006). Allocative efficiency of small-holder cocoyam farmers in Anambra State, Nigeria.Munich Personal RePEc Archive. MPRA Paper No. 17362, posted 17. Sep 2009. Online at http://mpra.ub.uni-muenchen.de/17362/

Onwueme, I. (1978).The tropical tuber crops: Yams, cassava, sweet potato and cocoyams. John Wiley \& Sons, 199-225

Opara, E., Njoku, T.C. and Isaiah, C. (2013). Potency of Some Plant Extracts and Pesticides on Bacterial Leaf Blight Diseases of Cocoyam (Colocasia Esculenta) in Umudike, South Eastern Nigeria. Greener Journal of agricultural Sciences 3(5): 312-319.

Osawaru M.E., Ogwu, M.C. (2014). Ethnobotany and Germplasm Collection of Two Genera of Cocoyam (Colocasia [Schott] and Xanthosoma [Schott], Araceae) in Edo State Nigeria. Science Technology and Arts Research Journal 3(3): 23-28

Perez-Ponce, J. (2007). Cocoyam. In: FAO Plant Production and Protection Paper 195: Quality declared planting material Protocols and standards for vegetatively propagated crops. Fajardo, J., Lutaladio, N., Larinde, M., Rosell, C., Barker, I., Roca, W. and Chujoy, E.(eds). FAO, Rome Italy. 140p

Rao, K.N. (2004). Plant genetic resources: Advancing conservation and use through biotechnology. African Journal of Biotechnology 3: 136-145.

Schnell, R.J., Goenaga R. and Olano C.T. (1999).Genetic similarities among cocoyam cultivars based on Randomly Amplified Polymorphic DNA (RAPD) analysis. Scientia Horticulturae, 80:267-276

Seetohul, S., Puchooa, D. and Ranghoo-Sanmukhiya, V. M. (2008).Genetic Improvement of Taro (Colocasia esculenta var esculenta) through in-vitro mutagenesis. University of Mauritius Research Journal, 13A: 1-11

Suja, G., Susan John, K. and Sundaresan, S. (2009). Potential of Tannia (Xanthosoma sagittifolium (L.)Schott.) for organic production. Journal of Root Crops 35(1):36-40.

Talwana, H.A.L., Serem, A. K., Ndabikunze, B. K,Nandi, J. O, Tumuhimbise, R., Kaweesi, T., Chumo, E.C. and Palapala, V. (2009). Production Status and Prospects of Cocoyam (Colocasia esculenta (L.)Schott.)in East Africa. Journal of Root Crops 35(1): 98-107

Williams, J.G.K., Kubelik, A.R., Livak, K.J., Rafalski, J.A. and Tingey, S.V. (1990). DNA polymorphisms amplified by arbitrary primers are useful as genetic markers. Nuclic Acids Research 18(22): 6531-6535. 